\title{
Justifying New Rights: Affectedness, Vulnerability, and the Rights of Peasants
}

\author{
Corina Heri* (1)
}

(Accepted 21 August 2019)

\begin{abstract}
Over the last decades, various groups seeking international legal recognition of new human rights claims have succeeded in their endeavors. Some movements have crafted such convincing demands that their participation has even become an implicit condition of the legitimacy of the resulting human rights documents. But what are the bases of claims for new human rights, and how do they help to confront the argument that human rights' expansion also entails their dilution? This Article explores narratives based on two different concepts, namely the political-science concept of affectedness and the legal-ethical concept of vulnerability. It does so by drawing on the process for the recognition of peasant human rights at the United Nations. The Article explores what it understands as the peasant critique of existing human rights by looking at the differences and interrelations between affectedness and vulnerability-based argumentation. It argues that an approach premised purely on affectedness, and thus focused on participation, is less empowering than one that includes a regard for vulnerability, which serves as a heuristic device for identifying and challenging inequalities, demands substantive outcomes, and can serve to craft a convincing theoretical account of human rights protections.
\end{abstract}

Keywords: Human rights law; vulnerability; peasant rights; affectedness; human rights subject

\section{A. Introduction and Key Concepts}

Human rights law is, in its essence, a site for contestation of abuses of State power, of inequalities, and of assaults on human dignity. Positive human rights protections-as enshrined in numerous regional and international treaties and recognized, at least in part, by every member State of the United Nations (UN) - have also been criticized as failing to adequately contest a number of pressing issues. These include the effects of unchecked corporate power, climate change, growing global inequality, and neoliberal and neo-colonial tendencies, among other issues. ${ }^{1}$ The failings of human rights law have been bemoaned by many, for example, by Samuel Moyn in his recent volume on the failure of human rights law to provide social and economic justice. ${ }^{2}$

What is to be done about these lacunae of the existing human rights framework? One avenue goes beyond litigating existing human rights-or seeking solutions outside the human rights framework altogether-and involves active engagement of individuals and their movements and organizations in the creation of new obligations on States and other actors. Alongside struggles to achieve the better implementation of existing human rights, some actors are thus looking to change the normative framework, either by seeking the recognition of previously

${ }^{\star}$ Corina Heri is a Postdoctoral Researcher at the University of Amsterdam.

${ }^{1}$ See, e.g., Samuel Moyn, Not Enough: Human Rights in an Unequal World (2018).

${ }^{2} I d$.

(C) The Author(s), 2020. Published by Cambridge University Press on behalf of the German Law Journal. This is an Open Access article, distributed under the terms of the Creative Commons Attribution licence (http://creativecommons.org/licenses/by/4.0/), which permits unrestricted re-use, distribution, and reproduction in any medium, provided the original work is properly cited. 
unrecognized rights or by providing a critique of this framework that exposes the assumptions and biases that prevent it from adequately capturing real-life harms and inequalities.

This idea of particular groups or movements claiming previously unrecognized human rights protections for themselves is certainly not new. One example is the involvement of civil society organizations in the negotiation of the United Nations Convention on the Rights of Persons with Disabilities. ${ }^{3}$ Another such struggle for human rights recognition, and the one discussed in this Article, is championed by self-identified peasants from across the globe, who have come together to contest developments in international trade law and neo-liberal trade policies as well as lacunae in the human rights framework. They have formed the international peasant movement, which-for present purposes-means the group of actors that has cooperated to claim international human rights protections for peasants, including, but not limited to, the movement known as La Vía Campesina (LVC). ${ }^{4}$ In doing so, they have often positioned themselves as outsiders, and thus as the "other" in free trade policies or capitalism. ${ }^{5}$ It could even be said-given their criticism of the existing human rights framework and the failure of that framework to adequately protect peasant interests - that peasants once positioned themselves as the "other" in human rights. ${ }^{6}$ Over time, however, peasants have become more willing to turn to international human rights law to advance their interests, and today they have articulated a variety of human rights claims. Initiated to a significant extent by LVC, a number of these rights have recently been discussed at the UN as it finalized its Declaration on the Rights of Peasants and other People Working in Rural Areas (UNDROP). On December 17, 2018, this draft text-which was prepared with the collaboration of LVC and other peasant-based movements, forums, and NGOs-was adopted by the UN General Assembly. ${ }^{7}$

The peasant movement's grassroots activism has exposed a number of major shortcomings in the existing human rights framework when it comes to adequately serving the needs and interests of peasants, thereby taking its place alongside or within the critique generally referred to as "Third World Approaches to International Law" (TWAIL), ${ }^{8}$ as well as other critiques of the existing system. In doing so, it has engaged with and advanced the argument that international human rights law in its current form fails to adequately contest and remedy elements of social, global, and environmental injustice, business responsibility for human rights, and the effects of neoliberalism. ${ }^{9}$ A number of the rights claims formulated by the peasant movement represent a pushback against these shortcomings, including the proposed rights to land and seeds and a novel understanding of the interests underlying the right to food in the form of what is known as the right to "food sovereignty." One of the main claims of the peasant movement has been-and continues to be-that peasants, their lands, and their crops are negatively affected by the international legal order and the inequalities and market-oriented approaches it allows or even favors. This claim is used as a springboard for the recognition of peasant-specific rights-both of substance and participation-on the same hierarchical level as the source of this impact-that is, the international legal order. As will be discussed in this Article, these efforts have the potential

\footnotetext{
${ }^{3}$ U.N. Convention on the Rights of Persons with Disabilities, Dec. 13, 2006, 2515 U.N.T.S. 3. See Janet E. Lord, Mirror, Mirror on the Wall: Voice Accountability and NGOs in Human Rights Standard Setting, 5 SeTON HALL J. DiPL. \& INT'L REL. 93 (2004).

${ }^{4}$ Peter Rosset, Participatory Evaluation of La Via Campesina 13 (2005), https://norad.no/globalassets/import2162015-80434-am/www.norad.no-ny/filarkiv/ngo-evaluations/evaluation-of-la-via-campesina-lvc.pdf.

${ }^{5}$ See Luis Hernández Navarro \& Annette Aurélie Desmarais, Crisis y soberanía alimentaria: Vía Campesina y el tiempo de una Idea, 153 El Cotidiano 89, 93 (2009).

${ }^{6}$ See id.

${ }^{7}$ See G.A. Res. 73/165, Declaration on the Rights of Peasants and Other People Working in Rural Areas (Dec. 17, 2018).

${ }^{8}$ For a discussion of TWAIL (Third World Approaches to International Law), see Antony Anghie, TWAIL: Past and Future, 10 Int'L Community L. Rev. 479 (2008); Antony Anghie, The Evolution of International Law: Colonial and Postcolonial Realities, 27 ThIRd WORLD Q. 739 (2006).

${ }^{9} \mathrm{Cf}$. Moyn, supra note 1 . For a history of neoliberalism as a global way of protecting capitalism, see QUINN SLOBODIAN, Globalists: The End of EMPire AND the BirTh of NeOliberalism (2018).
} 
to shift human rights law more firmly into the realm of transnational justice-understood here as a term that encompasses both political and social justice on the domestic level and global justice on the international plane. ${ }^{10}$

Any movement advocating for the creation of new human rights must defend itself against fears that such rights will be diluted by the proliferation of norms, that this "cheapens the purposes of human rights and correspondingly weakens the resolve of potential enforcers," and that it endangers intercultural assent to the international regime of human rights law. ${ }^{11}$ New human rights claims must therefore be in possession of a convincing theoretical foundation if they wish to overcome such criticism. The present Article will particularly focus on narratives based in two different concepts-the political science concept of affectedness and the legal-ethical concept of vulnerability - as ways of framing and justifying rights claims. While certainly not the only foundations for rights - in this regard, the fundamental values of equality and human dignity certainly bear mention-these two concepts, when compared, lead to insights about the why, the who, and the how of peasant rights.

On the one hand, we have the concept of affectedness, as set out in more depth in the following section. This concept is rather well-explored from a political science perspective and relates to the argument that those affected by a policy must have the right to participate in its formulation. ${ }^{12}$ This concept means that a normative order can only be considered just if it allows those affected by it to participate in its making. ${ }^{13}$ Starting from this perspective, human rights can be seen as "rights not to be subjected to social institutions or legal norms that cannot be properly justified toward those affected and rights to be equal participants in such procedures of justification." 14 This is largely a question of participation in policy-making processes. For example, to Carol C. Gould, those who are "importantly affected" by decisions made on the international plane can derive rights to be involved in the making of those decisions and must be able to influence or affect those decisions that have a significant effect on their economic ability to ensure their own subsistence. ${ }^{15}$

On the other hand, we have the concept of vulnerability. As a normative concept, vulnerabilityas theorized most prominently by Martha Albertson Fineman-responds to the limitations of efforts to secure equality, relates to the shared but differently manifested and socially-shaped risks of harms and misfortune that characterize human existence, and serves as a heuristic device allowing for the examination of hidden biases and assumptions. ${ }^{16}$ This means that vulnerability is a rightsgenerative concept that describes the assailability of all humans given their embodiment in a fragile and dependent physical form. ${ }^{17}$ Fineman has theorized this understanding of vulnerability as a critical endeavor ${ }^{18}$ and as a rejection of the "neoliberal fixation on personal responsibility" in favor of a legal subject that recognizes and incorporates differences. ${ }^{19}$ It is important to note that this is not the only account of vulnerability of note in the human rights context. Alongside Fineman's conception of vulnerability stands a second, less universal understanding of

\footnotetext{
${ }^{10}$ Leaning on the definition used in RaINER Forst, JUSTIFICATION AND CRITIQUE: Towards a CRITICAL TheORY OF POLITICS 67 (2014).

${ }^{11}$ See Michael Ignatieff, Human Rights as Politics and Idolatry (Amy Gutmann ed., 2001).

${ }^{12}$ See Sofia Näsström, The Challenge of the All-Affected Principle, 59 POL. STUD. 116 (2011).

${ }^{13}$ See Carol C. Gould, Interactive Democracy: The Social Roots of Global Justice 203 (2014).

${ }^{14}$ See Forst, supra note 10, at 65. Forst's concept of justification as a parameter for justice is distinct from-but has certain similarities to- the concepts of affectedness and vulnerability discussed herein.

${ }^{15} \mathrm{Id}$.

${ }^{16}$ See Martha Albertson Fineman, The Vulnerable Subject: Anchoring Equality in the Human Condition, 20 YALE J. L. \& FEMINISM 1 (2008).

${ }^{17}$ See Vulnerability: Reflections on a New Ethical Foundation for Law and Politics (Martha Albertson Fineman \& Anna Grear eds., 2013).

${ }^{18}$ See Martha Albertson Fineman, Vulnerability and Inevitable Inequality, 4 OsLo L. REV. 133 (2017).

${ }^{19}$ See Martha Albertson Fineman, Equality and Difference - The Restrained State, 66 ALA. L. REV. 609, 616-17 (2015).
} 
vulnerability. This approach-which is, for example, deployed by the European Court of Human Rights, along with other human rights bodies ${ }^{20}$-relates to experiences specific to particular groups and individuals, and serves not as a universal understanding of vulnerability, but as a way of identifying those who require particular protection.

Under both approaches, vulnerability reasoning draws on a justification inherent to the existing human rights system, namely one that recognizes the shared but differently-manifested need for protection of all human individuals. ${ }^{21}$ In doing so, it overlaps to some extent with the idea of providing protections based on identity, in the sense that some identities may generate particular risks and barriers to effective enjoyment of human rights and therefore entail entitlements to protection. But it is also broader and richer than identity because it does not require homogeneity and incorporates additional elements, for example, dependency or other situational risks of harm. ${ }^{22}$ Based on Fineman's argumentation about vulnerability as a foundation of human rights, scholars have interpreted the concept as a platform for advancing social justice, and as a way for clarifying State obligations to ensure substantive equality and protect human agency. ${ }^{23}$

These justifications for human rights-related claims-vulnerability and affectedness, but also the related notion of identity - are connected to the same underlying principles, namely preserving the dignity and agency of the persons concerned, which in turn means that these persons are protected or can protect themselves against harms and injustice. ${ }^{24}$ The present Article interrogates the ideas of vulnerability and affectedness as concepts which can do at least part of the heavy lifting when it comes to demanding new human rights claims that upset the status quo. In doing so, it draws on the process concerning the recognition of peasant rights. Based on the argument that LVC — and the peasant movement more broadly_can be taken as a paradigmatic example of self-representation by grassroots groups on the transnational plane, it explores the utility of affectedness-related and vulnerability-related arguments in human rights discourse and argues that these can overlap and reinforce each other.

As indicated above, this Article also, at various points, highlights that the peasant movement's claims are largely framed as claims based on (self-identification with) peasant identity. This aspect is used to inform the rest of the analysis, but it is not examined as such. Because identity and vulnerability overlap in the sense indicated above - and because human rights law largely lacks the well-theorized understanding of identity that exists in other disciplines-such a distinction is difficult to make here. ${ }^{25}$ Identity, even discriminated-against identity, does not necessarily entail human rights protections. For example, while positive human rights law protects people who are discriminated against because of identity-related grounds including their race, disability, or gender, it does not currently protect those who face discrimination because, for example, they are obese, even though they may in fact face real and harmful discrimination on this basis, and it is possible to formulate a convincing normative argument for prohibiting such discrimination.

\footnotetext{
${ }^{20}$ See Alexandra Timmer, A Quiet Revolution: Vulnerability in the European Court of Human Rights, in VULNERABILITY: Reflections on a New Ethical Foundation for Law and Politics, supra note 17, at 147; Audrey R. Chapman \& Benjamin Carbonetti, Human Rights Protections for Vulnerable and Disadvantaged Groups: The Contributions of the UN Committee on Economic Social and Cultural Rights, 33 Hum. RTs. Q. 682 (2011).

${ }^{21}$ See Martha Albertson Fineman, Equality, Autonomy, and the Vulnerable Subject in Law and Politics, in VULNERABILITY: Reflections on a New Ethical Foundation for Law and Politics, supra note 17, at 13.

${ }^{22}$ See Corina Heri, The Rights of the Vulnerable under Article 3 ECHR: Promoting Dignity, Equality and Autonomy by Reconceptualizing the Human Rights Subject (2017).

${ }^{23}$ See Carolina Yoko Furusho, Uncovering the Human Rights of the Vulnerable Subject and Correlated State Duties Under Liberalism, 5 UCL J. L. \& JURIS. 175, 177-78 (2016).

${ }^{24}$ See IGNATIEFF, supra note 11 , at 57.

${ }^{25}$ See Yussef Al Tamimi, Human Rights and the Excess of Identity: A Legal and Theoretical Inquiry into the Notion of Identity in Strasbourg Case Law, 27 Soc. \& L. STUd. 283 (2018); Identity Politics In THE Public Realm: Bringing Institutions BACK IN (Avigail Eisenberg \& Will Kymlicka eds., 2011) [hereinafter IDENTITY Politics].
} 
Other fields of study have developed a more complete understanding of how identities evolve and intersect, as well as the paradox that results from the personal nature of identity and its simultaneous shaping by mechanisms of power. ${ }^{26}$ Building a concept of what identity means in this context is beyond the scope of this analysis, and it will therefore accept as its premise that peasantness is an identity, as established elsewhere. ${ }^{27}$ Peasant identity — and the argument that peasants, because of their peasantness, face particular and severe human rights impacts—-will therefore be explored only to the extent necessary to determine how this relates to the topic at hand.

Some further delimitations are in order. First, this Article will not engage with the foundation of human rights law as such - be it in natural law, human dignity and agency, or another basis. On this, it defers to the work of others and accepts that both the protection of human dignity and agency are at the core of human rights protections as we understand them today. ${ }^{28}$ Second, it should be noted that the use of human rights argumentation by the peasant movement and the process towards the recognition of peasant human rights have been ably explored elsewhere from a number of disciplinary perspectives - for example, by Priscilla Claeys, Christophe Golay, Noha Shawki, Marc Edelman and Carwil James, Josh Brem-Wilson, Ingeborg Gaarde, and Smita Narula, among a number of others. ${ }^{29}$ The present Article does not purport to contest or reproduce their comprehensive and convincing accounts of the emergence of peasant rights claims, the need for recognition of these rights, and the evolution of the relevant claims over time, although it relies on their accounts at various points. Third, it should be noted that, from a political science perspective, LVC and the peasant movement can be explored as examples of norm contestation ${ }^{30}$ or of attempts to democratize global governance through civil society involvement. ${ }^{31}$ These processes, too, have been extensively documented and analyzed elsewhere and are beyond the scope of the present Article. ${ }^{32}$

What this Article aims to do is to ask what the interrelated concepts of affectedness and vulnerability can mean for human rights law, using the backdrop of peasant rights as a paradigmatic example. In other words, it asks: What role does affectedness play in the recognition of human rights claims, and how does this relate to the idea of vulnerability? Ultimately, this Article argues that an

\footnotetext{
${ }^{26}$ IDENTITY POLITICS, supra note 25.

${ }^{27} \mathrm{Cf}$. Annette Aurélie Desmarais, The Power of Peasants: Reflections on the Meanings of La Vía Campesina, 24 J. RURAL STUD. 138, 140 (2008) (as well as the discussion below).

${ }^{28} \mathrm{See}$, e.g., IGNATIEFF, supra note 11 (and the contributions therein).

${ }^{29}$ Priscilla Claeys, Food Sovereignty and the Recognition of New Rights for Peasants at the UN: A Critical Overview of La Via Campesina's Rights Claims over the Last 20 Years, 12 Globalizations 452 (2015); Priscilla Claeys, Human Rights and the Food Sovereignty Movement: Reclaiming Control (2015); Priscilla Claeys, The Creation of New Rights by the Food Sovereignty Movement: The Challenge of Institutionalizing Subversion, 46 Sociology 844 (2012); Christophe Golay, Legal Reflections on the Rights of Peasants and Other People Working in Rural Areas, in FIRST SESSION OF THE WORKING Group on the Rights of Peasants and Other People Working in Rural Areas 20 (2013), https://www.ohchr.org/ Documents/HRBodies/HRCouncil/WGPleasants/Golay.pdf; Noha Shawki, New Rights Advocacy and the Human Rights of Peasants: La Vía Campesina and the Evolution of New Human Rights Norms, 6 J. Hum. RTs. Prac. 306 (2014); Smita Narula, The Global Land Rush: Markets, Rights, and the Politics of Food, 49 STAN. J. InT'L L. 101 (2013); Marc Edelman \& Carwil James, Peasants' Rights and the UN System: Quixotic Struggle? Or Emancipatory Idea Whose Time has Come?, 38 J. Peasant Stud. 81 (2011); Josh Brem-Wilson, La Vía Campesina and the UN Committee on World Food Security: Affected Publics and Institutional Dynamics in the Nascent Transnational Public Sphere, 43 R. INT'L STUD. 302 (2017); Josh Brem-Wilson, Towards Food Sovereignty: Interrogating Peasant Voice in the UN Committee on World Food Security, 42 J. Peasant Stud. 73 (2015); Ingeborg Gaarde, Peasants Negotiating a Global Policy Space: La Vía Campesina in THE COMMITTEe ON WORLd FOOd SECURITY (2017).

${ }^{30}$ See Noha Shawki, Norms and Normative Change in World Politics: An Analysis of Land Rights and the Sustainable Development Goals, 28 Global Change Peace \& Sec. 249 (2016).

${ }^{31} \mathrm{Cf}$. the discussion in Civil Society Participation in European and Global Governance: A Cure for the Democratic Deficit? (Jens Steffek, Claudia Kissling \& Patrizia Nanz eds., 2008).

${ }^{32} \mathrm{Cf}$. much of the literature cited herein, especially, Michael Menser, Transnational Participatory Democracy in Action: The Case of La Via Campesina, 39 J. Soc. PHIL. 20 (2008); Maria Elena Martinez-Torres \& Peter M. Rosset, La Vía Campesina: The Birth and Evolution of a Transnational Social Movement, 37 J. PEASANT STUD. 149 (2010); RosseT, supra note 4; Desmarais, supra note 27.
} 
approach to human rights grounded in affectedness alone - and thus focused on participation - does not necessarily guarantee the outcomes in terms of substantive rights that those making the relevant human rights claims desire. In this regard, vulnerability-based argumentation may be more promising, or at least a much-needed complement to affectedness. In other words, while affectedness-based arguments may hold promise for the legitimacy of global governance processes, they do not per se guarantee better protection for the human rights subjects concerned.

This Article will fit claims to peasant rights protection and arguments about affectedness into the existing literature on human rights claims grounded in vulnerability, ${ }^{33}$ and it will proceed in three parts. To begin, given that affectedness is a rather unusual topic in the human rights law context, it will explore what this concept means for present purposes. It will then explore the meaning of peasantness and make the case that peasant rights claims as they are currently being made relate to both the concepts of affectedness and vulnerability. Last, it will look at both vulnerability and affectedness as concepts that can empower struggles for human rights and for justice and evaluate what the usefulness of both concepts is for rights discourse.

\section{B. The Concept of Affectedness and its Relevance for Human Rights Law}

From a political studies perspective, affectedness has been explored as a concept that allows for democratic decision-making by identifying "those at a distance who should be able to provide input into discourses and decisions when they are importantly affected by a given decision or policy." 34 In other words, this means that those who are "importantly affected" by decisions made on the international plane can derive rights to be involved in the making of those decisions, and in fact must be able to influence decisions that have a significant effect on their economic ability to ensure their own subsistence. ${ }^{35}$

In a recent special edition of Third World Thematics concerning the issue of affectedness, Jan Sändig, Jochen von Bernstorff, and Andreas Hasenclever described a turn to affectednessparticipation in global governance, which they see as addressing the legitimacy problems of international policy-making and transnational governance and promising a more inclusive and legitimate global politics. ${ }^{36}$ In the same special edition, Josh Brem-Wilson discussed affectedness as a basis for global governance with "a crucial bottom-up, non-elite character, pivoting on the autonomous agency of affected publics themselves." ${ }^{37}$ Affectedness has been criticized by some as implying potentially limitless causal chains triggered by an endless number of events and causes, a concern which has brought about a precision in the form of the "all-subjected" principle, which sifts relevant from irrelevant triggers and effects. ${ }^{38}$ Despite this-given its promise for boosting the legitimacy of policies easily criticized for their lack of democratic control and removal from the real world of the non-elite or the non-West-the concept continues to be lauded for its promise. ${ }^{39}$

What, then, does this mean for human rights law? The conclusion that follows from the above is that affectedness in one's human rights entitlements entails a right to participation in the setting of norms that affect these rights. The idea of all-affected interest is thus seen as setting the

\footnotetext{
${ }^{33}$ Including Vulnerability: Reflections on a NeW ETHICAL Foundation fOR LAW AND Politics, supra note 17; Kirsten Sandberg, The Convention on the Rights of the Child and the Vulnerability of Children, 84 NORDIC J. INT'L L. 221, (2015); Martha Albertson Fineman, The Vulnerable Subject and the Responsive State, 60 EMORY L. J. 251 (2010); Timmer, supra note 20; Chapman \& Carbonetti, supra note 20; Furusho, supra note 23.

${ }^{34}$ See Gould, supra note 13 , at 203.

${ }^{35} I d$.

${ }^{36}$ See Jan Sändig, Jochen Von Bernstorff \& Andreas Hasenclever, Affectedness in International Institutions: Promises and Pitfalls of Involving the Most Affected, 3 THIRD World Thematics 587, 588 (2018).

${ }^{37}$ See Josh Brem-Wilson, Legitimating Global Governance: Publicisation, Affectedness, and the Committee on World Food Security, 3 Third World Thematics 605, 618 (2018).

${ }^{38} I d$. at 606 , with further references.

${ }^{39}$ See Sändig, Von Bernstorff \& Hasenclever, supra note 36, at 587-88.
} 
boundaries of the demos that should be allowed to participate in normative activity. ${ }^{40}$ For present purposes, it should be noted that while affectedness is not often termed as such in the human rights law context, the idea that those who are affected in their human rights can derive legal effects from this affectedness is not new, but it is indeed a basic tenet of international human rights law. As Anne Peters has argued, the very premise of making international remedies for human rights violations available to individual applicants is one that allows claims from those who are directly affected in their rights. ${ }^{41}$ In addition, within the indigenous rights context, there is a growing consensus - and in the UN Declaration on the Rights of Indigenous Peoples (UNDRIP), a recognition ${ }^{42}$ - of the obligation to obtain the free, prior, and informed consent (FPIC) of indigenous peoples to development projects that affect their lands. ${ }^{43}$ It has even been argued that the principle of participation in the making of decisions by which one is affected is a foundational underlying, albeit understudied, principle of human rights law. ${ }^{44}$

The question, then, is whether affectedness is simply another name for human rights impacts or violations - and therefore describes any given group of individuals who are negatively affected in their rights by a particular measure or decision - or whether this concept means something more, implies collective entitlements, or applies at a lower threshold of interference-that is, where there has not necessarily been a rights violation. In particular, it is possible to ask whether affectedness is a rights-generative concept, for example, one that gives rise to entitlements of its own right, and not simply a way of determining when existing entitlements are imperiled. This question is particularly relevant given the concept of vulnerability, which, for the purposes of human rights law, can be understood as a rights-generative concept that gives rise to special entitlements. ${ }^{45}$ For example, the vulnerability of children - or in other words, the recognition that this group is in need of special protection - can be seen as the foundation of the recognition of children's rights. ${ }^{46}$ In this regard, it can be asked whether, like vulnerability, the concept of affectedness goes beyond a procedural requirement of participation or representation and instead also entails substantive protections.

\section{LVC as a Movement of Affected and Vulnerable Peasants}

As indicated above, the present analysis will use the peasant rights context to clarify the meaning of affectedness and vulnerability in the human rights context. This means looking at the international peasant movement, as exemplified by, but certainly not limited to, LVC. This movement has taken an active role in the Human Rights Council's work to draft a declaration of peasant rights. In doing so, it represents a rather striking example of self-representation by a grassroots organization on the transnational level. The following will preface the further analysis by briefly contextualizing LVC and exploring the controversial definition of the peasantry, as well as evaluating the law-making role of the movement. This will serve as the foundation for the argument that LVC is a paradigmatic example of a grassroots movement claiming rights that protect peasants against transnational policies on the basis of their affectedness by these policies. This same

\footnotetext{
${ }^{40}$ See Robert E. Goodin, Enfranchising All Affected Interests, and Its Alternatives, 35 PHIL. \& PuB. AfF. 40 (2007); Zoltan Miklosi, Against the Principle of All-Affected Interests, 38 Soc. Theory \& Prac. 483 (2012).

${ }^{41}$ See Anne Peters, Membership in the Global Constitutional Community, in The Constitutionalization of INTERNATIONAL LAW 153 (Jan Klabbers et al. eds., 2010).

${ }^{42}$ G.A. Res. 61/295, Declaration on the Rights of Indigenous Peoples, at art. 32, 2 (Sept. 13, 2007).

${ }^{43}$ See Hans Morten Haugen, Deciding on Land and Resources: How to Increase the Influence of the Most Affected Within Communities?, 7 Hum. RTs. \& InT'L Legal Discourse 262 (2013).

${ }^{44}$ See Nicholas McMurry, Deepening Democracy: Participation under International Human Rights Law (2017).

${ }^{45}$ On this concept, see Vulnerability: Reflections on a New Ethical Foundation for Law and Politics, supra note 17.

${ }^{46}$ See Sandberg, supra note 33 , at 223.
} 
finding can also be framed differently, namely in terms of peasants' vulnerability to human rights impacts linked to these policies and the imbalances of power that make them possible.

\section{The Peasant Rights Movement and Defining the Peasantry}

For present purposes, the history of the modern international peasant movement began in the 1970 s and 1980s in the face of neoliberal policies that negatively affected smallholder farming. ${ }^{47}$ Peasant movements quickly identified actors and processes beyond national borders-namely transnational corporations (TNCs), international capital flows, and the international trade regulation they influenced-as responsible for the plight of peasants. This led peasants to internationalize as well, joining forces with likeminded organizations abroad based on the common recognition that small producers were being massively displaced by "fiat, force and finance." 48 Today, LVC has 182 member organizations from 81 countries around the globe and claims to represent more than 200 million peasants. ${ }^{49} \mathrm{LVC}$ 's work redefines the spaces for peasant participation by drawing unity from the diversity of its member organizations and creating an avenue through which peasants can directly participate in international decision-making. ${ }^{50}$

Who, then, are the peasants represented by LVC and other, similar organizations? ${ }^{51}$ LVC, at its inception, sought to reclaim the term "peasant" from its pejorative connotations in the English language. Like other stigmatized groups that have reclaimed pejorative descriptors, peasants have thus taken a term characterized by negative implications and adopted it as a "marker of solidarity" and a politicized identity. ${ }^{52}$ Indeed, Annette Aurélie Desmarais has argued that this reclaiming of identity has been one of LVC's greatest accomplishments. ${ }^{53}$

That accomplishment has translated to the UN level. The UNDROP, in its Article 1, defines a peasant as:

[A]ny person who engages or who seeks to engage alone, or in association with others or as a community, in small-scale agricultural production for subsistence and/or for the market, and who relies significantly, though not necessarily exclusively, on family or household labour and other non-monetized ways of organizing labour, and who has a special dependency on and attachment to the land. ${ }^{54}$

This definition is broad and inclusive, and goes on to explicitly include a number of other activities related to "artisanal or small-scale agriculture," as well as indigenous, transhumant, nomadic people, the landless, and migrant and seasonal agricultural workers. ${ }^{55}$ The UNDROP language not only refers to peasants' "special dependency on and attachment to the land" as a definitional element of peasantness, but also notes in its preamble that peasants disproportionately suffer from poverty, hunger, and malnutrition. They also suffer from the effects of environmental degradation

\footnotetext{
${ }^{47}$ See Martinez-Torres \& Rosset, supra note 32, at 149-150, 150-153; RossET, supra note 4, at 7-8; Hernández Navarro \& Desmarais, supra note 5, at 91 .

${ }^{48}$ Philip McMichael, A Comment on Henry Bernstein's Way with Peasants, and Food Sovereignty, 42 J. PEASANT STUD. 193, 193 (2014).

${ }^{49} 29$ New Members Accepted into La Via Campesina During the 7th Conference, LA Vía CAMPesina. (Oct. 6, 2017), https:// viacampesina.org/en/29-new-members-accepted-la-via-campesina-7th-conference/.

${ }^{50}$ See Desmarais, supra note 27 , at 141.

${ }^{51}$ See Claeys, The Creation of New Rights by the Food Sovereignty Movement: The Challenge of Institutionalizing Subversion, supra note 29 , at $853-54$.

${ }^{52} \mathrm{Cf}$. Mary Elizabeth Beaton \& Hannah B. Washington, Slurs and the Indexical Field: The Pejoration and Reclaiming of Favelado 'Slum-dweller', 52 LANGUAGE SCI. 12 (2015) (mentioning terms such as "favelado" or "queer"); Desmarais, supra note 27 , at 140 .

${ }^{53}$ Desmarais, supra note 27 , at 140 .

${ }^{54}$ G.A. Res. 73/165, Declaration on the Rights of Peasants and Other People Working in Rural Areas (Dec. 17, 2018).

${ }^{55}$ Id. at art. 1, g9 2-4.
} 
and climate change and face "several factors [that] make it difficult ... to make their voices heard, to defend their human rights and tenure rights." It thereby indicates an understanding of peasants as a group that are entitled to claim rights because of their special agriculture-related dependence and exposure to negative human rights impacts-for example, their vulnerability, which is distinct from, but akin to, the close, explicitly spiritual connection to land more closely associated with the indigenous rights movement.

In this regard, it should be noted that there are clearly a number of parallels between peasant and indigenous rights movements, both in terms of their ways of organizing and in many of the rights they seek. As Priscilla Claeys and Deborah Delgado Pugley have written, both movements have global political agendas, both are concerned with climate change and access to land, and both are linked to collective identities that reposition peasants and indigenous peoples-who were both once considered anachronisms in the modern world- "as modern actors embodying the key to alternative development models" who are making claims based in the human rights framework and concerned with eking out a space of sovereignty and autonomy vis-à-vis State power. ${ }^{56}$ Although there may be overlaps here and a difficulty in drawing sharp distinctions, the present analysis focuses particularly on peasant rights and the peasant movement, and on its specific claims, which are largely concerned with the concepts of food sovereignty, seed sovereignty, land sovereignty, and limiting the negative impacts of neoliberalism on peasants. The premise here is that many peasants do not benefit from the protections created for indigenous peoples, and in this sense, the peasant rights movement can be understood as a way of paralleling certain protections created in the indigenous rights context for a broader group suffering parallel but not identical harms.$^{57}$ In this regard, the argument could be made that peasants meet at least some of the elements of a definition of "peoples" as having the right to self-determination: They share a historical tradition and common economic life, arguably self-identify as a people, and have institutions to express their will for identity, for example, LVC. ${ }^{58}$ At the same time, peasants live all around the world, and territorial self-determination within the existing model of the nation-state is out of the question. Instead, what they are seeking is self-determination over their means of production and their livelihoods.

To be clear, the idea of peasants as capitalism's other ${ }^{59}$ and the essentialism of envisioning peasant communities as homogenous and solidary has been contested by those who see the under-theorization of stratification and divisions due to gender, age, ethnicity, and class in peasant societies as a strategic choice made to advance the peasant agenda. ${ }^{60}$ Others have retorted that unification is nonetheless desired and needed "to blunt the singular force and violence of commodification of land, labor, genetic resources and knowledges," ${ }^{\prime}$ linked to small producers' tenuous hold on their land, which is an effect of WTO policy and enclosure by mass land grabs. ${ }^{62}$ Philip McMichael has, in this vein, argued that peasantness "is not about categorical purity; rather, it is about a multi-faceted counter-movement feeling its way into the future." 63

Though the peasant movement does not require a strict definition of peasantness and recognizes that it does not exclusively represent peasant interests, ${ }^{64}$ in the interest of legal clarity and foreseeability — and in order to prevent abuses—a legal text like the UNDROP, and especially any

\footnotetext{
${ }^{56}$ See Priscilla Claeys \& Deborah Delgado Pugley, Peasant and Indigenous Transnational Social Movements Engaging with Climate Justice, 38 CAN. J. DEv. STUD. 325, 330-331 (2017).

${ }^{57}$ See Yorck Diergarten, Indigenous or Out of Scope? Large-scale Land Acquisitions in Developing Countries, International Human Rights Law and the Current Deficiencies in Land Rights Protection, 19 Hum. RTs. L. Rev. 37 (2019).

${ }^{58}$ As per the definition in the UNESCO Final Rep. and Recommendations of an International Meeting of Experts on the Further Study of the Concept of the Right of People, U.N. Doc. SHS.89/CONF.602/7 (Feb. 22, 1990).

${ }^{59}$ See Henry Bernstein, Food Sovereignty Via the 'Peasant Way': A Sceptical View, 41 J. Peasant Stud. 1031, 1044 (2014).

${ }^{60} I d$. at $1046,1056$.

${ }^{61}$ See McMichael, supra note 48, at 199.

${ }^{62} I d$. at 199.

${ }^{63} \mathrm{Id}$. at 200.

${ }^{64} C f$., Hannah Wittman, Interview: Paul Nicholson, La Vía Campesina, 36 J. PEASANT Stud. 676, 680 (2009).
} 
future legally binding instruments, do require categorical purity to some, albeit not an absolute, extent. In other words, while peasantness need not be a narrow category-and self-identification as a peasant is an important element of any definition ${ }^{65}$ - human rights law requires human rights holders, and rights that are guaranteed to some but not others do require a way of distinguishing the two. This is one further difference between the approach to indigenous rights in the UNDRIP and the approach to peasant rights in the UNDROP, because the former operates on the basis of identification, not definition, while in the peasant context the UNDROP Working Group took great pains to craft a definition of the peasantry.

At the same time, when it comes to the issue of defining peasants, peasant representatives have emphasized that peasantness is an identity characterized by a common marginalization. The cohesion involved in this identity - the unity in diversity proclaimed by LVC-is achieved through a common, deliberatively decided strategy and what the movement calls its mística: An expression of culture and social reality that allows members to understand peasants as diverse but united through the fact that "the crisis of rural family agriculture is the same all over the world. The causes are the same, [t]he reality is the same, and the same neoliberal, or more plainly, capitalist policies have caused this crisis." ${ }^{66}$ Like many other social movements-the LGBTQI rights movement, feminism, and the Civil Rights movement in the United States, for example- the peasant rights struggle contests injustice done to a particular group. ${ }^{67}$ This injustice is to some extent defining: Although, as stated at the outset, an in-depth analysis of identity is beyond the scope of this analysis, ${ }^{68}$ it can be noted that the idea of peasantness as an identity is largely premised around the idea of the negative effects of neoliberal policies specifically on peasants. The fact that peasants are particularly affected by these policies is portrayed as legitimizing their search to change them, including through human rights claims. It is therefore possible to describe LVC as an example of direct self-representation by the grassroots at the transnational level based on and organized around a common experience stemming from the negative effects of neoliberal policies. In other words, peasants' affectedness by these policies is presented as a legitimization of their struggle against them, including of their human rights claims.

Alternatively, this can be framed as an issue of vulnerability, in the sense outlined in the Introduction to this Article and further explored below in Section D.III. In this regard, vulnerability represents a critique of formal approaches to equality and a rejection of the "neoliberal fixation on personal responsibility" in favor of a legal subject that recognizes and incorporates differences. It also serves to recognize not just the reality of human fragility, but also the fact that because of this fragility, human individuals are dependent on and embedded in social relationships and institutions such as the family, market, or State. ${ }^{69}$ Inequalities in access to the resources, termed "sources of resilience" by Fineman, distributed by these institutions explain why—although we are all equally vulnerable in terms of our being human-some humans are in better positions than others. ${ }^{70}$ Vulnerability as a critique furthermore serves to reject the individualism of applying economic modeling to manifold contexts and of framing differences between individuals as the result of individual choice, which society need not subsidize, support, or even really address. ${ }^{71}$

So how do these ideas about addressing inequality by contesting individualism and taking into account dependence and embeddedness apply in the peasant context? First, the fact that peasants particularly depend on the land and on various resources such as water and seeds-as well as on

\footnotetext{
${ }^{65}$ See Justin Kenrick \& Jerome Lewis, Indigenous Peoples' Rights and the Politics of the Term 'Indigenous', 20 ANTHROPOLOGY TODAY 4, 5 (2004).

${ }^{66}$ See Wittman, supra note 64 , at 678.

${ }^{67}$ See IDENTITY POLITICS, supra note 25.

${ }^{68}$ See id.

${ }^{69}$ See Fineman, Vulnerability and Inevitable Inequality, supra note 18, at 134.

${ }^{70} \mathrm{Id}$. at 147.

${ }^{71} I d$. at 140.
} 
the market-coupled with the ways in which resources, favor, and advantages are bestowed by existing institutions in a way that is disadvantageous to them, is linked to the dependence and embeddedness-related aspects of vulnerability theory. ${ }^{72}$ Second, a further link can be made to the fact that much of the world's population, in turn, depends on peasants to produce their food. When it comes to the individualism aspect, it can be argued that the pursuit of a peasant way of life is more than just an individual choice interchangeable with any other choice. This is because it is part of a context, namely, a complex web of social and institutional relationships that gives rise to structural inequalities and it therefore requires law and policy to be shaped in a way that addresses the inequalities that affect peasants in this context. ${ }^{73}$ In short, neoliberally-shaped policies and decisions are destroying the livelihoods of peasants. These peasants therefore have a right to participate in the formulation of these policies-from an affectedness perspective- and to be effectively protected against the policies' real, lived effects in a way that examines how advantages are distributed, that promotes equality, and that protects their agency from a vulnerability perspective.

\section{Peasants as Law-Makers?}

It is undeniable that grassroots peasant rights organizations have had an influence on the UN's work to draft the UNDROP. Examples of this include LVC's own drafting of such a declaration, which kick-started the whole UNDROP process, ${ }^{74}$ and the inclusion of peasant representatives in five successive rounds of deliberations on the text of the UNDROP. Peasants' involvement in the preparation of the Declaration and the consultation requirements envisioned therein, as discussed below, underscore an idea which also shaped the indigenous rights recognition process, namely that "people who are the subject of a rights document are entitled to participate in its framing."75 The peasant rights movement is piggybacking on that right with clear success. ${ }^{76}$ In this vein, its participation in the norm-making process on the international plane would serve as evidence of the idea that affectedness generates participation rights. In this regard, this Article will not argue that because peasants are affected by the international order-and they have successfully participated in normative processes that are part of that order-there is a general right of all affected persons or peoples to participate in these processes. Instead, we can only consider this as an example of what affectedness-based participation can look like.

What, then, has the value of affectedness-based participation been to date? By bringing about an international dialogue about peasant rights on the UN level, the peasant movement has initiated and decisively shaped the development of new human rights - or at least new-ish ones, given the overlap with existing rights. In other words, the movement has taken the first step in a typical pattern for obtaining the recognition of new human rights - such as the preparation of a non-binding declaration by the UN, potentially to be followed by binding instruments later on-and has rather decisively influenced the shape those rights have ended up taking.

This, in some sense, positions LVC as a law-making, or at least a law-shaping or law-drafting, force. LVC's success in managing to bring about and shape a process that led to the creation of new human rights norms evokes larger questions that concern the human rights framework as a whole. Where do such rights come from? Who decides what their content should be? From where do they derive their authority and legitimacy? Does the proliferation of rights dissipate the urgency and coherence of the human rights project? These questions do not have easy answers.

As stated previously, it should be noted that the idea of a non-state actor participating in normative processes is by no means unheard of under international law, or more specifically

\footnotetext{
${ }^{72}$ See Fineman, The Vulnerable Subject and the Responsive State, supra note 33, at 262, 264-266, and 269.

${ }^{73}$ See Fineman, Vulnerability and Inevitable Inequality, supra note 18, at 140-41.

${ }^{74} \mathrm{Cf}$. La Vía Campesina, Declaration of the Rights of Peasants - Women and Men art. 1 (2009) https:// viacampesina.org/en/wp-content/uploads/sites/2/2011/03/Declaration-of-rights-of-peasants-2009.pdf.

${ }^{75}$ See Edelman \& James, supra note 29, at 94.

${ }^{76} I d$. at 95 .
} 
under international human rights law. ${ }^{77}$ Admittedly, the idea of a radical counter-establishment agricultural social movement as a law-maker, or something similar, raises questions. At the same time, this has proven to be, at least to some extent, the reality of the peasant rights process. In this regard, it is possible to invoke the argument that law is law, not only if and when it is authoritative, but also if and when it is persuasive. ${ }^{78}$ In other words, law must not only be created by a source that has the authority to do so-in this case the UN, which adopted the UNDROP, and leaving aside for a moment the fact that the UNDROP is a non-binding instrument-but it must also be sufficiently coherent and compelling to be considered legitimate by States and non-State actors alike.

So what is the relevance of LVC's participation for the legitimacy of the UNDROP and other, binding peasant rights instruments that could conceivably follow? The present Article will not argue that LVC has a formal law-making status and admits that it would be rather difficult to make this argument. Instead, it submits that, at this point, and while LVC's claims do not have normative force on their own, LVC has taken such a powerful position in the peasant rights sphere that the drafters of a peasants' rights instrument on the UN or any other level would struggle to defend its legitimacy without the movement's input or blessing. In this sense, LVC's involvement has a degree of normative force because it bolsters the legitimacy of any project on peasant rights. This allows it to have an influence on what Jean d'Aspremont has called law-makers' law-ascertainment, or the methods through which rules of international law are identified and formalized. ${ }^{79}$

This is not the only example of stakeholder involvement in human rights law-making or lawevolving processes. As noted above, such involvement is by no means unusual. The involvement of disability rights groups in the recognition of specific human rights relating to persons living with a disability and of indigenous movements in the recognition of indigenous peoples' rights are clear examples. What is exceptional here-and what this Article aims to flag-is the extent of LVC's involvement and representativeness and the indispensability of its support, which may at least in part be due to its presentation of a united and unwavering vision for peasant human rights in the relevant law-making process. The term "law-ascertainment" fits well here because, in much of this process, there is a sense that peasant human rights already exist, that the peasant movement knows what they are, and that the UN is simply ascertaining what these rights are by formally recognizing them, with peasants' support. In addition, as will be discussed below, it is striking that much of the peasant rights discourse is framed in terms of sovereignty-over land, seeds, and food-thereby at least conceptually impinging on the State's sovereign domain.

\section{Affectedness, Vulnerability, and Rights Discourse}

If the peasant movement is a grassroots one that directly represents peasants who are threatened-and to some extent constituted-by the condition of being affected by neoliberal policies, the question then is what this means for the actual rights claims being made and how this relates to the concept of vulnerability discussed above.

\section{Peasantness as Critique}

Framing any claims as human rights claims means to some extent accepting the constraints imposed by the liberal underpinnings of these rights - their Western, individualist basis, their

\footnotetext{
${ }^{77}$ See Jean d'Aspremont, Non-state Actors in International Law: Oscillating Between Concepts and Dynamics, in Participants in the International Legal System: Multiple Perspectives on Non-State Actors in INTERNATIONAL LAW 1, 4 (2011).

${ }^{78}$ See Paul Schiff Berman, A Pluralist Approach to International Law, 32 YALE J. INT'L L. 301, 303 (2007).

${ }^{79} \mathrm{See}$ Jean d'Aspremont, Non-state Actors from the Perspective of Legal Positivism: The Communitarian Semantics for the

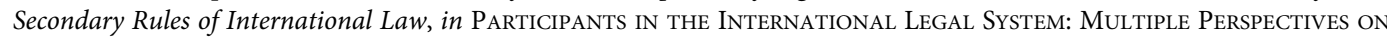
Non-State Actors in InTERnational Law 23, 23-27 (2011).
} 
focus on State obligations - as opposed to those of private actors or TNCs - and their emphasis of economic liberty. ${ }^{80}$ But there are also a number of advantages to rights framing: It not only has a uniting power, and can legitimize and lend visibility to the claims in question, ${ }^{81}$ but it also represents an opportunity to challenge human rights law's constraints and problems. The peasant movement has brought such a challenge by making claims that promise to expand the very foundations of rights, from individual to collective, from State-oriented to addressed to all relevant actors, from based on economic liberty to premised on resource-sharing, accessibility, inclusivity, and sustainability, from something that is created top-down to an entitlement that is demanded bottom-up, from shaped by patriarchy to gender-equal and inclusive. ${ }^{82}$ It can now certainly be argued that peasantness - like indigenous identity-is being used to push back against globalization, cultural uniformity, the effects of colonialism, and corporate exploitation. ${ }^{83}$ In this sense, peasant rights claims are being used to counter homogenized ideas about the human rights subject.

By highlighting fundamental imbalances in the global order-which have not been successfully contested by means of international human rights law to date-the peasant movement has formulated a critique of neoliberalism that reflects some of the same interests as the TWAIL critique of international law. These interests include the aim to lend a voice to a systemically underrepresented point of view, to encourage solidarity among those underrepresented actors, and to address the effects of globalization on self-determination. ${ }^{84}$ The peasant critique furthermore transcends the North-South debate and hones in on the imbalances of power that characterize neoliberalism, including the supremacy of capital vis-à-vis labor. In this context, it can be noted that Balakrishnan Rajagopal has argued that while the so-called third world was, in the 1960s and 1970s, made up of newly independent and developing States, today it is represented largely by social movements. ${ }^{85}$ Thus, it is now the "effervescent and troublesome cauldron of peasants, women, environmentalists, human rights activists, indigenous people, religious activists, and other individuals" that challenges injustice and inequality. ${ }^{86}$ In this sense, the peasant critique of existing human rights protections can be understood as a main ingredient in this cauldron and as a new frontier of TWAIL.

To what extent does this critique demand the recognition of new rights, as opposed to reiterating existing ones? There are many rather evident overlaps between peasant rights and existing rights such as the right to food, health, just and favorable conditions of work, social security, an adequate standard of living, non-discrimination, and housing. In addition, the UN has recognized the right to water, ${ }^{87}$ and there is also the aforementioned overlap with indigenous rights and the idea of resource sovereignty, ${ }^{88}$ along with a potential argument to be made concerning the right to self-determination. In other words, many of the rights claims made by peasants do not go beyond-or far beyond-existing rights as interpreted today by the relevant bodies, and some simply restate these rights specifically for peasants. But, there are some claims that do transcend the current mainstream normative framework. Thus, the idea of a right to land is a relative novelty, as is the right to seeds or to food sovereignty. Therefore, it is

\footnotetext{
${ }^{80}$ See Priscilla Claeys, Human Rights and the Food Sovereignty Movement: Reclaiming Control, supra note 29.

${ }^{81}$ See Wittman, supra note 64 , at 679.

${ }^{82}$ On this last part, cf. Nettie Wiebe, Women of La Via Campesina: Creating and Occupying our Rightful Spaces, in LA VIA Campesina's Open Book: Celebrating 20 Years of Struggle and Hope, https://viacampesina.org/en/wp-content/ uploads/sites/2/2013/05/EN-01.pdf (last visited Nov. 2, 2018).

${ }^{83}$ See Ronald Niezen, The Origins of Indigenism: Human Rights and the Politics of Identity 2, 5 (2003).

${ }^{84}$ On TWAIL, cf. Anghie, supra note 8 (both sources).

${ }^{85}$ See Balakrishnan Rajagopal, From Resistance to Renewal: The Third World, Social Movements, and the Expansion of International Institutions, 41 HARV. INT'L L. J. 529, 533 (2000).

${ }^{86} I d$. at 539.

${ }^{87}$ G.A. Res. 64/292 (July 28, 2010) (declaring safe and clean drinking water and sanitation a human right essential to the full enjoyment of life and all other human rights).

${ }^{88}$ G.A. Res. 1803 (XVII), Permanent Sovereignty over Natural Resources (Dec. 14, 1962).
} 
possible to speak here of "new-ish" rights claims. Even when there are overlaps with existing rights, for example, between the right to food and the right to food sovereignty, formulating these claims as separate from existing rights is significant, because it allows peasants to shape their meaning and gain leverage concerning their content and application.

\section{The Added Value of Affectedness-Based Arguments}

The question here is whether basing rights claims on affectedness really adds something to the peasant rights struggle. Certainly, the existence of the UNDROP project implies a recognition of the human rights-related problems facing peasants, and their involvement in the project indicates an institutional willingness to hear the affected. Generally speaking, however, affectedness comes more substantively into play when it comes to participatory or consultation rights, as a way of delineating the scope of these rights.

The UNDROP contains a number of references to affectedness, or the state of being affected. Thus, it contains a general obligation of States to consult peasants and other rural workers before making decisions that may affect them-including international agreements-and to do so "through their own representative institutions"; this should be done while "taking into consideration existing power imbalances between different parties and ensuring active, free, effective, meaningful and informed participation of individuals and groups in associated decision-making processes." 89 The Declaration also provides for a peasant right to "active and free participation ... in the preparation and implementation of policies, programmes and projects that may affect their lives, land and livelihoods" 90 and "the right to seek, receive, develop and impart information, including information about factors that may affect the production, processing, marketing and distribution of their products." 91

What is particularly striking, in this regard, is what is missing. The requirements of FPIC that were present in earlier versions of the UNDROP ${ }^{92}$ have now been struck from the text. Although they may to some extent be covered in substance elsewhere in the UNDROP, the failure to explicitly include FPIC requirements carries meaning. ${ }^{93}$ The worry here, from a peasant rights perspective, is that participation in and of itself-without a need to obtain peasants' consent, and thus without granting peasants a veto right over decisions that affect them-will not lead to better outcomes for peasants and may actually be harmful to their agenda by serving to tranquilize dissent. ${ }^{94}$

The idea of affectedness as a method of placing the affected on more equal footing with the State relates to LVC's use of the language of food sovereignty, which raises a provocative implication. Indeed, in the context of human rights law, references to sovereignty generally refer to the sovereignty of the State over its territory. Instead of simply trying to create State obligations to regulate land in a certain way-for example, to adequately protect peasant farmers-this approach places the same sovereign power with the peasants themselves as, it seems, both human rights subjects and the knowers of the morally true content of these human rights, undistorted by trade interests. Peasant representatives have made clear that this is not an attack on State sovereignty over territory, but a call for empowerment. ${ }^{95}$ At the same time, this type of empowerment

\footnotetext{
${ }^{89}$ See G.A. Res. 73/165, supra note 7, art. 2 g 3.

${ }^{90}$ See id., art. 10 . 1.

${ }^{91}$ See id., art. 11.

${ }^{92}$ Human Rights Council Res., Declaration on the Rights of Peasants and Other People Working in Rural Areas, U.N. Doc. A/HRC/WG.15/1/2, art. 4 (June 20, 2013).

${ }^{93}$ G.A. Res. 73/165, Declaration on the Rights of Peasants and Other People Working in Rural Areas, U.N. Doc. A/RES/73/ 165 (Dec. 17, 2018).

${ }^{94}$ See Rosset, supra note 4 , at 12 .

${ }^{95}$ Fifth Session of the Open-Ended Intergovernmental Working Group on a United Nations Declaration on the Rights of Peasants and Other People Working in Rural Areas, Statement by the World Forum of Fisher Peoples (WFFP), (Apr. 9-13, 2018).
} 
does not follow the traditional human rights approach of protecting individuals from abuses of State power but instead shifts decision-making from the State to individuals, in effect claiming a decision-making sphere free of the State. In other words, the food sovereignty claim buttresses participation demands by evoking a decision-making or veto right of the most affected-in this case, food producers and consumers-as a group. ${ }^{96}$ In doing so, it encapsulates the usefulness of reliance on affectedness for the peasant rights movement. ${ }^{97}$ This usefulness also has some limits, however. In particular, in addition to jettisoning the protections granted by existing human rights and potentially homogenizing the group in receipt of participation rights, ${ }^{98}$ it does not say all that much about how approaches to food should be substantively reshaped in order to better serve peasant producers, food consumers, and the environment.

\section{Vulnerability as a Basis for Peasant Rights}

When it comes to the distinction between affectedness on the one hand and vulnerability to rights impacts on the other hand, it is interesting to note that, at the first and second sessions of the Working Group on the UNDROP, the ninth preambular recital of the draft text considered that "peasants constitute a specific social group which is so vulnerable that the protection of their rights requires special measures to make sure that States respect, protect and fulfil their human rights. " ${ }^{99}$ By the third session of the Working Group, in the 2016 version of the draft, this recital had disappeared. ${ }^{100}$ While references to a "specific social group" were jettisoned, the idea of the vulnerability of peasants continued to permeate the discussions of the Working Group. ${ }^{101}$ Ultimately-and despite repeated calls to protect peasants on the basis of their vulnerability-the 2018 Declaration instead refers to the fact that peasants and other rural workers "suffer disproportionately" from human rights impacts such as poverty and hunger, as well as the fact that "several factors" impede their ability "to make their voices heard, to defend their human rights and tenure rights, and to secure the sustainable use of the natural resources on which they depend." 102

So what, precisely, is vulnerability, and what does it do for human rights entitlements? As mentioned above, vulnerability language has been referred to in the relevant scholarship as a source of rights, a justification for redistribution of resources, and a heuristic device for identifying injustice. As understood by leading vulnerability scholar Martha Albertson Fineman, vulnerability as a rights-generative concept emphasizes the shared humanity of all human rights subjects and requires a State that is responsive to individuals' material needs by providing access to certain social goods. ${ }^{103}$ The concept is used in various ways by a number of human rights bodies, including the UN Committee on Economic, Social and Cultural Rights (CESCR) ${ }^{104}$ and the European Court of Human Rights. ${ }^{105}$ Thus, vis-à-vis persons with disabilities, the CESCR has, for example, found that States' obligation

\footnotetext{
${ }^{96}$ See Jochen von Bernstorff, 'Community Interests' and the Role of International Law in the Creation of a Global Market for Agricultural Land, in COMmunity InTERESTs Across InTERnAtional LAW 278-296 (Eyal Benvenisti \& Georg Nolte eds., 2018) (distinguishing participation and veto rights).

${ }^{97} \mathrm{Id}$.

${ }^{98}$ See Tina D. Beuchelt \& Detlef Virchow, Food Sovereignty or the Human Rights to Adequate Food: Which Concept Serves Better as International Development Policy for Global Hunger and Poverty Reduction, 29 AgRiculture \& Hum. VAlues 259, 269 (2012).

${ }^{99}$ H.R.C Res., supra note 92.

${ }^{100}$ Human Rights Council Res., Declaration on the Rights of Peasants and Other People Working in Rural Areas, U.N. Doc. A/HRC/WG.15/3/2 (Mar. 8, 2016).

${ }^{101} C f$. Human Rights Council Res., U.N. Doc. A/HRC/33/59, (July 20, 2016).

${ }^{102}$ G.A. Res $73 / 165$, supra note 7 , preamble, fifth recital, sixth recital \& eleventh recital.

${ }^{103}$ See Fineman, The Vulnerable Subject and the Responsive State, supra note 33.

${ }^{104}$ See Timmer, supra note 20.

${ }^{105}$ See Chapman \& Carbonetti, supra note 20.
} 
in the case of such a vulnerable and disadvantaged group is to take positive action to reduce structural disadvantages and to give appropriate preferential treatment to people with disabilities in order to achieve the objectives of full participation and equality within society for all persons with disabilities. This almost invariably means that additional resources will need to be made available for this purpose and that a wide range of specially tailored measures will be required. ${ }^{106}$

Vulnerability, deployed as a basis for rights, need not necessarily portray those affected as victims or essentialize their experiences, although those risks do exist and must be accounted for. ${ }^{107}$ It can, instead, be seen as varied concrete expressions of a shared human experience that is characterized by dependence and interrelatedness, and as a pendant to resilience to harms. ${ }^{108}$ Understood in this way, vulnerability provides a framework for identifying sources of resilience and ensuring access to these resources; it can be used to contextualize people, to recognize imbalances of power, and to further substantive equality in a way that does not require the performance of a specific identity. ${ }^{109}$ It also allows for a recognition of the fact that autonomy and self-sufficiency are not intrinsic to the legal subject, but they are generated by the structures within which we are embedded. ${ }^{110}$

In other words, while affectedness entails participation and a check on State discretion, vulnerability entails intensified attention to imbalances in the ways in which advantages are distributed, including the ways in which the State protects the interests of different groups and individuals. Vulnerability serves to identify inequalities and demands State action and special attention to ensuring compliance with the full range of obligations in the respect-protect-fulfill triad. It therefore has the power to definitively prohibit certain incompatible State action, while rights claims based on affectedness place the affected on more equal discursive footing with the State.

In their own ways, both vulnerability and affectedness hold promise for the recognition of new and especially of collective rights: Vulnerability, as a way to emphasize the effects of inequality and the need to ensure access to sources of resilience-which, in the peasant context, could mean land, for example - and affectedness, as a way to emphasize the need for meaningful participation.

In addition, vulnerability and affectedness arguably overlap, in the sense that the former allows for the identification of situations in which people lack a voice in various decision-making processes that concern them, thereby addressing the participation dimension of equality. ${ }^{11}$ This reflects the all-affected principle, that is, the understanding that all those affected-or at least affected to a given threshold or level of significance-by a given decision or policy should correctly be entitled to participate in its formation. In this regard, it should be reiterated, as stated above, that there are different interpretations of vulnerability. Some human rights bodies fail to understand vulnerability as a universal human experience and use it only as a way to identify certain groups or individuals in need of particular protection, to the detriment of those who are not considered vulnerable and possibly also of those who are. ${ }^{12}$ Thus, if the focus is not placed on universal human vulnerability but on particular vulnerabilities - for example, the vulnerability of children - then the range of addressees of vulnerability-based entitlements is narrower, and the potential for stigmatization and patronization is greater. ${ }^{113}$ To avoid these pitfalls,

\footnotetext{
${ }^{106}$ U.N. CESCR, 11th Sess., General Comment No. 5: Persons with Disabilities, U.N. Doc. E/1995/22 (Dec. 9, 1994).

${ }^{107}$ See Timmer, supra note 20.

${ }^{108}$ See Fineman, The Vulnerable Subject and the Responsive State, supra note 33, 14-16; Fineman, Vulnerability and Inevitable Inequality, supra note 18.

${ }^{109}$ See Fineman, The Vulnerable Subject and the Responsive State, supra note 33.

${ }^{110}$ See id.

${ }^{111}$ See SANDra Fredman, Discrimination LaW 25-33 (2d ed. 2011), especially page 31, as noted in Lourdes Peroni \& Alexandra Timmer, Vulnerable Groups: The Promise of an Emerging Concept in European Human Rights Convention Law, 11 INT'L J. Const. L. 1056, 1074-75 (2013).

${ }^{112}$ For example, this is the approach used by the European Court of Human Rights; $c f$. HeRI, supra note 22.

${ }^{113}$ See Goodin, supra note 40.
} 
vulnerability-based rights claims should incorporate an understanding of the fact that vulnerability is a universal human experience, even if it is expressed in different ways. If used in this way, vulnerability promises rights claims that are richer in substance than the focus on participation suggested by the all-affected principle.

In this context-which places the emphasis on the affected humans of human rights - it is interesting to note that LVC lobbies for rights that affect all of humanity, or even go beyond humanity, for example, into the environmental arena. Thus, all humans are-due to their necessary embodiment in a physical form-dependent on sustenance through food, and the interests related to the right to food sovereignty concern us all. Also, LVC has championed and potentially broadened the concept of universality by exploring the interconnectedness of all human rights and of all living organisms on Earth. ${ }^{114}$ This is a form of implicit vulnerability analysis, and the movement might therefore benefit from relying more fully on that concept, which highlights the relational and interdependent nature of embodied life dependent on material resources and the environment provided by planet Earth. ${ }^{115}$

A vulnerability-based approach to peasants' rights could, for example, present land as a source of resilience to which access must be secured in order to counter the vulnerability of the affected individuals. Loss of land by those whose livelihood depends on it, by contrast, aggravates vulnerability and requires a State response. So, too, focusing on universal, but differently-experienced and differently-manifested, human vulnerability can transcend an equality analysis based on improving the situation of one identity group and can instead help tackle systemic imbalances of power and privilege by bringing about a reexamination of accepted structures and institutions. ${ }^{116}$ In other words, applying a vulnerability lens is advantageous because of its heuristic power to uncover existing imbalances and inequalities.

The universality element deserves some further attention. During the final session of the UN Working Group to draft the UNDROP — before that text was ultimately adopted by the UNGA in December 2018 - the European Union representative argued against the endeavor as a whole by submitting that the recognition of new rights that would be applicable only to persons living and working in rural areas would undermine the universality of rights. ${ }^{117}$ This argument had been made a month before by Rosa Freedman in a workshop concerning the expansion of human rights organized by the EU Directorate-General for External Policies. ${ }^{118}$ This argument is entirely unconvincing: Human rights for specific groups have been recognized any number of times, whether it be in the context of forbidding discrimination for some aspects of identity or not for others, or when it comes to creating special instruments to address specific vulnerabilities-for example, those of children, people living with disabilities, women, and other groups. These efforts are ultimately all about ensuring human dignity for every person-universally, but in different ways and through different approaches - as required by the exigencies of specific situations, contexts, risks, and dependencies. Presenting the recognition of group-specific human rights as a zero-sum game- that is, one in which the recognition of one group's rights entails a loss for another-favors a conservative and unevolving understanding of human rights law. That type of understanding means human rights will grow ever more woefully inadequate for responding to real and pressing issues that arise in an ever-changing world, and therefore for addressing human rights impacts brought about, for example, by international trade policies, business activities, and climate change. This is because while these issues affect humanity as a whole, they also have

\footnotetext{
${ }^{114}$ For an overview of these arguments, see Claeys, Human Rights AND THE Food Sovereignty MovemENT: RECLAIMING CONTROL, supra note 29, for example at 110.

${ }^{115}$ On this concept, see Vulnerability: Reflections on a New Ethical Foundation for Law and Politics, supra note 17.

${ }^{116}$ See Fineman, The Vulnerable Subject and the Responsive State, supra note 33, at 1-2.

${ }^{117}$ Based on the author's own notes of the session, held in Geneva from April 9-13, 2018.

${ }^{118}$ See Rosa Freedman, in Expansion of the Concept of Human Rights: Impact on Rights Promotion and Protection, Workshop, at 7 , DROI, (Mar. 20, 2018), http://www.europarl.europa.eu/RegData/etudes/STUD/2018/603865/EXPO_STU(2018)603865_EN.pdf.
} 
specific and non-negligible harmful impacts on rural people who depend on the natural world for their livelihood. If human rights are to protect real human beings, universality should not mean a stagnation of standards or a formalistic view that negates differences between various groups and individuals. Human rights law cannot manufacture equality by negating difference, and in fact, this only entrenches inequality more deeply and makes it more insidious.

In essence, a vulnerability-based analysis allows us to think normatively-wondering how human rights should be-while reflecting on the shared and messy neediness, interconnectedness, and dependency of human life. As a critique, vulnerability reveals the ways in which unequal distributions of power and existing legal structures support, facilitate, or maintain injustice and-in the human rights context-blind spots in protection. Recalling that the human rights subject must be understood as a vulnerable one in order to adequately reflect what is human means reattaching human rights law to evolving human experience and the manifold forms of real-life harms and inequalities.

\section{E. Conclusion}

This idea of particular groups or movements claiming previously unrecognized human rights protections for themselves is certainly not new. One example of this comes from the grassroots representatives of peasants and rural workers who took a very active role during the process to draft a UN Declaration on the Rights of Peasants and Rural Workers. Looking at the peasant struggle for rights recognition allows for reflection about how the creation of new human rights is justified and how it can be defended against concerns about human rights proliferation. This requires rights to have a convincing theoretical foundation, which the present Article has sought in narratives based in two different concepts, namely the political science concept of affectedness and the legal-ethical concept of vulnerability.

The peasant movement's involvement in the drafting of the UNDROP represents an example of a social movement exercising the privilege, or perhaps right, of those who are directly affected by decisions made on the international plane to participate in their making. Peasantness is to some extent constituted by the negative effects of neoliberal policies on peasants and rural workers: While rural farmers already faced hunger, malnutrition, poverty, and landlessness before the advent of neoliberalism as it exists today, it has specific effects on peasants-for example, through market-oriented policies that lead to the loss of land. By applying the lens of affectedness, these effects can be understood as generating a necessity on the part of the actors driving normative processes to involve peasants in the process of discussing and recognizing their human rights entitlements, at least if they intend for the outcomes of those normative processes to be considered legitimate and convincing.

In other words, when it comes to the substance of peasant rights-like in the indigenous rights context - arguments based on affectedness can be useful to generate rights to participation and consultation. By contrast, reliance on the vulnerability paradigm generates a critique of an approach to rights premised on the idea of autonomy and self-sufficiency, and lacking an understanding of power imbalances and unequal access to resources; it also allows for an emphasis on the relationality of human existence in embodied form dependent on the physical and finite resources of our planet.

Both of these concepts, affectedness and vulnerability, can therefore hold meaning for any struggle for the recognition of new human rights entitlements. In the peasant rights context, affectedness-based argumentation aims to allow peasants to participate in decision-making so that the outcomes of decisions can be shaped to be more in their favor. Alternatively, a vulnerabilitybased approach allows them to identify the ways in which the existing order fails to work in their favor and accords them an unequal amount of privilege and power, while also showing why a response is required and even indicating what that response should look like. Emphasizing 
vulnerability—and not just affectedness—-thus holds substantial promise for peasant rights and for any other movement for the recognition of human rights claims furthering the cause of transnational justice.

Acknowledgements. I am grateful to Jan Sändig and Jochen von Bernstorff for comments on an earlier version of what ultimately became this article. All errors are, of course, my own.

Financial Support. This work was supported by the Jaarsma-Adolfs Fund.

Cite this article: Heri C (2020). Justifying New Rights: Affectedness, Vulnerability, and the Rights of Peasants. German Law Journal 21, 702-720. https://doi.org/10.1017/glj.2020.35 